\title{
Narrating Illegal Logging Across the Globe Between Green Protectionism and Sustainable Resource Use
}

Winkel, Georg; Leipold, Sina; Buhmann, Karin ; Cashore, Ben; de Jong, Wil; Nathan, Iben; Sotirov, Metodi; Stone, Michael

\author{
Document Version \\ Final published version
}

Published in:

International Forestry Review

DOI:

10.1505/146554817822407367

Publication date:

2017

\section{License}

Unspecified

Citation for published version (APA):

Winkel, G., Leipold, S., Buhmann, K., Cashore, B., de Jong, W., Nathan, I., Sotirov, M., \& Stone, M. (2017). Narrating Illegal Logging Across the Globe: Between Green Protectionism and Sustainable Resource Use. International Forestry Review, 19(Supplement 1), 81-97. https://doi.org/10.1505/146554817822407367

Link to publication in CBS Research Portal

\section{General rights}

Copyright and moral rights for the publications made accessible in the public portal are retained by the authors and/or other copyright owners and it is a condition of accessing publications that users recognise and abide by the legal requirements associated with these rights.

Take down policy

If you believe that this document breaches copyright please contact us (research.lib@cbs.dk) providing details, and we will remove access to the work immediately and investigate your claim. 


\title{
Narrating illegal logging across the globe: between green protectionism and sustainable resource use
}

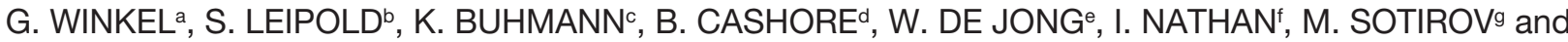 \\ M. STONE ${ }^{\mathrm{h}}$
}

\author{
${ }^{a}$ Head of Research Programme Resilience, European Forest Institute, Bonn Office, Germany \\ ${ }^{b}$ Assistant Professor, Forest and Environmental Policy Group, University of Freiburg, Germany \\ 'Professor, Department of Management, Society and Communication; Copenhagen Business School, Denmark \\ ${ }^{d}$ Professor, Yale School of Forestry \& Environmental Studies, Yale University, USA \\ 'Professor, Centre for Southeast Asian and Integrated Area Studies, Kyoto University, Japan \\ ${ }^{f}$ Associate Professor, Global Development, IFRO, University of Copenhagen, Denmark \\ ${ }^{8}$ Senior Researcher \& Team Leader, Forest and Environmental Policy Group, University of Freiburg, Germany \\ ${ }^{h}$ Research Affiliate, University of California Santa Barbara, USA
}

Email: georg.winkel@efi.int, sina.leipold@ifp.uni-freiburg.de,kbu.msc@cbs.dk, benjamin.cashore@yale.edu, dejongwil@cseas.kyoto-u.ac.jp, in@ifro.ku.dk, metodi.sotirov@ifp.uni-freiburg.de, michaelwstone@aya.yale.edu

\begin{abstract}
SUMMARY
In the last decade illegal logging has triggered the attention of policy makers and scholars of international forest governance. The issue is multifaceted, involving aspects of social and environmental sustainability, development, trade, access to markets and competitiveness. A vivid academic debate has resulted, exploring the nexus between markets and trade on one hand, and environmental and social sustainability on the other. The purpose of this paper is systematically assess the international policy discourse on illegal logging and legality verification policies in different regions of the world, drawing on the concept of policy narratives. Specifically, we analyse and compare policy narratives in Australia, Cambodia, China, the EU, Indonesia, Peru and the US. Our analysis is grounded on a rich empirical basis consisting of 260 interviews conducted by various researchers, numerous conversations with practitioners, policy documents and a media analysis. We find striking differences across the globe in narratives about illegal logging and legality verification and conclude that these need to be considered when assessing the support for, and the current and potential effects of, the emerging legality verification regime.
\end{abstract}

Keywords: global forest governance, legality verification, narratives, illegal logging, forest policy

Etat de la coupe de bois illégale à travers le monde: entre le protectorat vert et une utilisation durable des ressources

\section{G. WINKEL, S. LEIPOLD, K. BUHMANN, B. CASHORE, W. DE JONG, I. NATHAN, M. SOTIROV et M. STONE}

La coupe de bois illégale a attiré l'attention des créateurs de politique et des érudits de la gestion forestière internationale durant cette dernière décennie. La question comporte plusieurs facettes, incluant des aspects de durabilité sociale et environnementale, le commerce, le développement l'accès aux marchés et la compétitivité. Un débat académique vigoureux en a résulté, explorant d'une part les liens entre les marchés et le commerce et la durabilité environnementale et sociale d'autre part. Le dessein de ce papier est d'évaluer systématiquement le discours de politique internationale sur la coupe de bois illégale et les politiques de vérification légale dans diverses régions du monde, en s'inspirant du concept de narration politique. Nous analysons et comparons spécifiquement les narrations politiques en Australie, au Cambodge, en Chine, aux Etats-Unis, en Indonésie, au Pérou et dans l'Union Européenne. Notre analyse est ancrée sur une riche base empirique, consistant de 260 interviews conduites par divers chercheurs, de nombreuses conversations avec les acteurs, de documents de politique et d'analyse médiatique. Nous découvrons des différences marquées dans les narrations de la coupe de bois illégale et de la vérification légale à travers le globe et en concluons qu'elles doivent être prises en compte dans l'évaluation du soutien accordé au régime de vérification légale émergeant ainsi que dans l'observation de ses effets potentiels et actuels.

\section{Narrando la tala ilegal a través el mundo: entre proteccionismo verde y el uso sostenible de recursos}

\section{G. WINKEL, S. LEIPOLD, K. BUHMANN, B. CASHORE, W. DE JONG, I. NATHAN, M. SOTIROV y M. STONE}

La tala ilegal ha sido desde la última década un tema de preocupación para políticos y académicos de gobernanza forestal internacional. El tema es complejo y toca aspectos de sostenibilidad social y ambiental, desarrollo económico, comercio, acceso a mercados y competitividad. A raíz 
de eso, se ha generado un intenso debate académico. El propósito de este artículo es de evaluar sistemáticamente el discurso en la política internacional de la tala ilegal y las políticas de verificación de legalidad de la madera en diferentes regiones del mundo, usando el concepto de narrativas políticas. Específicamente, analizamos y comparamos narrativas de verificación de la legalidad de la madera de Australia, Cambodia, China, la Unión Europea, Indonesia, Perú y los EEUU. Nuestro análisis se basa en fuentes empíricos que incluyen 260 entrevistas a investigadores, conversaciones con actores del sector, documentos de políticas y un análisis de los medios de comunicación. Encontramos diferencias sorprendentes en las narrativas sobre tala ilegal y verificación de la legalidad de la madera en diferentes regiones del mundo. Concluimos que se debería tomar en cuenta estas diferencias, cuando se evaluara el apoyo a, y los efectos del emergente régimen de la verificación de legalidad de la madera.

\section{INTRODUCTION}

Illegal logging is a major issue debated in both environment and development discourses. While it is in the nature of the issue that accurate statistics are lacking, the overall dimension is seen as being significant (with shares of more than $50 \%$ of overall logging activities being estimated to be illegal in several important forest countries, cf. Gan et al. 2016). Illegal logging is connected with environmental challenges such as tropical deforestation and sustainable forest management, as well as crucial development issues such as free trade, national sovereignty over natural resources and good forest governance (Cashore and Stone 2012, McDermott et al. 2014).

For a long time international political initiatives tackling illegal logging targeted countries seen as major producers of illegal wood (so-called "producer countries", e.g. Indonesia or Ghana, cf. Wiersum and Ekands 2013). Policy schemes such as the Forest Law Enforcement, Governance and Trade Action Plan (FLEGT) of the European Union (EU) promote measures to support these countries to enforce their own forest laws and thereby advance their economic development as well as social and environmental stewardship in the forestand land-use sector (cf. Van Heeswijk and Turnhout 2013).

This approach has changed remarkably in the last ten years. A new generation of policies has emerged that target major wood-consuming markets in industrialized nations (so-called "consumer countries" - the dichotomy producer and consumer countries is widely used in the policy discourse, but neglects the importance of many 'consumer' countries as producers, and reversely 'producer' countries as consumers, see Leipold and Winkel 2016). This is done by prohibiting the import of timber harvested in contravention to the laws of the country of origin. The first of these policies was the 2008 amendment of the US Lacey Act through the Legal Timber Protection Act, which was quickly followed by the EU Timber Regulation (EUTR) in 2010 and the Australian Illegal Logging Prohibition Act in 2012.

All three laws together are portrayed as forming a newly emerging global legality verification regime (cf. Bartley 2014, Overdevest and Zeitlin 2014). Together with the previous initiatives, which target 'producer' countries directly, this regime is viewed as holding the potential to globally promote development and environmental goals related to forest management and the whole forest product chain. However, the specific effects of the legality verification regime are subject to controversial debates. While some scholars expect an enhanced promotion of "environmental and social stewardship in the forest sector" (Cashore and Stone 2012: 1), others point to possible adverse effects such as "disproportionate burdens on smallholders" (McDermott et al. 2014: 8) or even see incentives for "governments to weaken their laws" (Bartley 2014: 105, see also Cashore and Stone 2014).

In this paper we assume that the effects of the global legality verification regime will crucially depend on its interpretation (and resulting practices) across different regions of the world, including 'producer' and 'consumer' countries (note that we will use this politically established dichotomy throughout this paper, however we will critically reflect on it at the end, based on our findings). A key to understanding this regime and its possible effects on societies, economies and the world's forests is the analysis of the narratives connected to the regime's emergence and implementation.

In the literature up to now, narratives on illegal logging and the emerging global legality verification regime have only been analysed in 'consumer' countries, i.e. the US, the EU and Australia (Leipold et al. 2016, Leipold and Winkel 2016, Sotirov et al. 2017). This research shows that the development of the regime - specifically the development of the three laws that mainly constitute the regime - required a significant shift in the narratives on illegal logging that re-interpreted environment and development discourses, resulting in a shift of global responsibilities connected to illegal logging. Narratives on illegal logging and the emerging global legality verification regime in 'producer' countries have yet to be systematically analysed. An analysis of these narratives is crucial as the emerging regime is meant to influence global wood trade flows and the connected forest policy and management practices in both the 'Global North' and the 'Global South'.

Against this background, this paper aims to identify and contrast major narratives on illegal logging and the emerging legality verification regime in 'consumer' (specifically in the US, the EU, Australia) and 'producer' (specifically in China, Indonesia, Cambodia and Peru) countries. The US, the EU and Australia were selected because their new legislations built the cornerstone of the legality regime (see above); also, they are crucial wood product consumers (and producers) in the global market. China and Indonesia were selected as they are two powerhouses in the global wood product market (with China being the biggest producer and consumer) and are both very much involved in the global debates on the legality verification regime. Cambodia and Peru were selected as they represent two developing nations with a high share of illegal 
logging activities and a limited formal participation in global wood (products) trade. Moreover, Cambodia is a potentially significant exporter of illegally harvested wood in the region (Global Forestry Services et al. 2014), and in Peru, illegal logging has in recent years repeatedly reached an extraordinary level of political attention which has resulted in intense political debates about the issue there (Sears and Pinedo 2011). While these countries and regions remain a selection from a much larger set of possible countries and regions (e.g., Africa is not represented), we believe that this selection is representative enough to allow for insightful findings. Hence, based on the portrayal of narratives in these regions across the globe, we then identify and discuss consequences for the impact and relevance of global forest governance.

\section{ANALYZING POLICY NARRATIVES}

Narratives can be understood as consistent political stories about an issue. The analysis of narratives is tightly connected to the argumentative (or interpretive) turn in the political sciences (Forester 1993), which emphasizes that political problems and solutions are not just there, but need to be manufactured through processes of truth production. In such processes, narratives (or "stories", cf. Bevir and Rhodes 2002, McBeth et al. 2005, Roe 1994) are the "lifeblood of politics" (McBeth et al. 2007: 88). They are the thread "by which policy makers explore social and physical factors and events in order to organize complexity and render it governable by constructing intervention logics via problematizations, offering governance arrangements and assigning responsibilities" (Winkel 2014: 87; referring to Stone 2002, Gottweis 2003).

Narratives are "both the visible outcome of differences in policy beliefs (McBeth et al. 2005) and the equally visible outcome of political strategizing" (McBeth et al. 2007: 88). They are hence the result of stakeholders' perceptions and entail a strategic element by representing a certain perception of truth in policy making. In this way, narratives "create a fine web of stories that circulate in a policy arena, connect to superordinate discourses, and either stabilize or destabilize given policy arrangements by providing legitimacy, or orchestrating paradoxes, crisis, and need for change" (Winkel 2014: 87).

Narratives involve the identification and description of the problem (i.e., what is seen as problem - we refer to this in the following as "problematization"), problem solutions, actors and their subject positions (the actor's different roles and responsibilities), as well as perceived implications, threats and opportunities within and across these stories. These very dimensions make them accessible to analysis, and will be explored in the following by bringing together the extensive research data of the participating research groups.

\section{METHODS}

Table 1 provides an overview of the social science data used in this paper to represent the narratives in illegal logging and the legality verification regime.
In view of identifying narratives, the data analysis has been guided by the same set of jointly developed analytical questions for each case, focussing on national policy discourses (or supranational in the case of the EU). These questions are:

1. Who is debating illegal logging and related politics in the respective countries/regions? Can major discourse coalitions (i.e. authors sharing a specific narrative) be identified and who is engaged in these coalitions?

2. What are the most important narratives on illegal logging and the emerging legality verification regime in different parts of the world? Specifically,

a. what issues are presented as major problems related to illegal logging and illegal logging policies?

b. who is presented as having the responsibility to act on illegal logging and what does the preferred policy solution look like?

c. what major rhetoric figures (e.g. key terms, metaphors and dichotomies) are reproduced in the narratives (e.g. "developed North" vs. "less developed South"; environment vs. development; legality vs. sustainability etc.))?

d. which issues/aspects are excluded?

e. how are the implications (e.g. on forests, forest management and forest-related livelihoods) of the different laws making up the regime perceived in the analysed countries?

In the following, the most prominent narratives are presented for each of the case study regions. Subsequently, we compare narratives across the cases, highlighting similar patterns and notable differences, also with regard to the coalitions producing these narratives in different parts of the world. Finally, we draw conclusions on the potential implications of different ways the global legality verification regime is framed for its further evolution and impact.

\section{COUNTRY STUDIES}

\section{Narrating illegal logging in 'consumer' countries}

\section{United States}

The policy discourse in the US coalesced in relation to amendments to, and implementation of, the Lacey Act in 2008 through the Legal timber Protection Act - which were aimed at stopping illegal timber from accessing the US domestic market. Two major discourse coalitions emerged during these domestic debates, which developed opposing narratives. The first coalition included ENGOs, particularly the Environmental Investigation Agency, and to a lesser extent WWF and Greenpeace, alongside the US domestic timber industry, mainly represented by the American Forest and Paper Association. This industry-environmentalist coalition developed a narrative that problematized illegal logging in two related ways: a) as an environmental challenge related to deforestation in 'producer' countries mostly in the Global South and; 
TABLE 1 Data per country/region

\begin{tabular}{|c|c|c|c|}
\hline Country/Region & Interviews & Documents and other data & $\begin{array}{l}\text { Detailed } \\
\text { publication of the } \\
\text { case data (insofar } \\
\text { existent) }\end{array}$ \\
\hline Australia & $\begin{array}{l}8 \text { (with various stakeholders including industry, NGOs } \\
\text { and government) conducted } 2014 \text { and } 2015\end{array}$ & 38 policy documents & Leipold et al., 2016 \\
\hline Cambodia & $\begin{array}{l}20 \text { (with various stakeholders including government } \\
\text { staff, representatives of development agencies and } \\
\text { industry, local leaders and local people) conducted } 2011\end{array}$ & $\begin{array}{l}28 \text { newspaper articles, } 5 \text { NGO } \\
\text { reports, } 5 \text { policy documents }\end{array}$ & \\
\hline China & $\begin{array}{l}107 \text { ( } 43 \text { with various stakeholders including policy } \\
\text { makers, civil society leaders and business officials; } 64 \\
\text { with forest users and local forest officials) conducted } \\
2011 \text { and } 2012\end{array}$ & & $\begin{array}{l}\text { Cashore and Stone, } \\
2014\end{array}$ \\
\hline European Union & $\begin{array}{l}45 \text { (with various stakeholders including forest owners, } \\
\text { forest industry, environmental NGOs, national } \\
\text { governments and EU institutions) conducted } 2013 \text { and } \\
2014\end{array}$ & 31 policy documents & Sotirov et al., 2017 \\
\hline Indonesia & $\begin{array}{l}49 \text { (with various stakeholders including policy makers, } \\
\text { civil society leaders and industry officials) conducted } \\
2011 \text { and } 2012\end{array}$ & & $\begin{array}{l}\text { Cashore and Stone, } \\
2014\end{array}$ \\
\hline Peru & $\begin{array}{l}\text { Email exchanges with } 3 \text { key forestry experts; multiple } \\
\text { informal interviews with forestry experts over a period } \\
\text { of over } 20 \text { years and participation in multiple forestry } \\
\text { forums conducted in } 2015\end{array}$ & $\begin{array}{l}\text { Several reports produced for } \\
\text { policy makers, national and } \\
\text { international audiences, and } \\
\text { research papers; } \\
\text { Assessment of news stories, } \\
\text { and videos produced by public } \\
\text { media that are accessible } \\
\text { through the Internet database } \\
\text { provided by Mejia } \text { et al. (2015) } \\
\text { Recently completed country- } \\
\text { wide study on the country's } \\
\text { timber sector, which included } \\
\text { legality compliance }\end{array}$ & $\begin{array}{l}\text { Caillaux and } \\
\text { Chirinos, 2003; } \\
\text { Cornejo-Arana, } \\
\text { 2007; EIA, 2012; } \\
\text { Mejia et al., 2015; } \\
\text { Sears and Pinedo, } \\
2011\end{array}$ \\
\hline United States & $\begin{array}{l}31 \text { (with various stakeholders including industry, NGOs } \\
\text { and government) conducted in } 2013 \text { and } 2014 .\end{array}$ & $\begin{array}{l}19 \text { informal conversations, } 103 \\
\text { policy documents }\end{array}$ & $\begin{array}{l}\text { Leipold \& Winkel, } \\
2016\end{array}$ \\
\hline
\end{tabular}

b) as an issue of unfair competition from importers who outcompete responsible American producers by importing much cheaper, but illegal, wood. The policy solution offered by this coalition was to require every company along the supply chain to exercise due care to avoid importing illegal timber, and to develop penalties for non-compliance. Key rhetorical figures include reference to criminals and to American values of fairness and patriotism (protecting US producers against dubious foreign competitors). Notably, the environmental and industry partners in the coalition purposefully agreed to exclude any mention of sustainability in the debate and instead focused on legality (as the first would have redirected the focus from forest management practices in other countries to possibly also include the US, an idea that was strictly opposed by the industry). Moreover, while the link between illegal logging and deforestation was emphasized, the potentially more significant contribution of legal land conversion from forest to agricultural lands (to meet rising consumption) was excluded from this narrative (Leipold and Winkel 2016).

A second distinct narrative in the US policy debate on illegal logging was voiced by a coalition formed of importing wholesalers, and later, building and large retailing companies, including musical instrument retailers whose products often include tropical wood. This coalition did not question the importance of illegal logging as a major environmental policy problem. Instead, they offered a narrative that promoted international voluntary measures to support producers in the Global South to improve their domestic forest governance. Moreover, they criticized the US law as a backdoor protectionist policy aimed at unfairly increasing rent for domestic wood producers, resulting in government overreach that could threaten innocent American manufacturers, retailers and consumers. While their rhetoric was rather muted before the legislative changes, this coalition has become more vocal over time, asserting that the Lacey Act amendments went far 
beyond the good intentions connected to tackling illegal logging (Leipold and Winkel 2016).

In sum, the US debate on illegal logging predominately revolved in relation to the Legal Timber Protection Act (amending the Lacey Act) and its implementation, where two distinct policy narratives developed. While the problematic nature of illegal logging as an issue in the Global South was consensual in the US, deep disagreement about the preferable policy solution existed. Moreover, the connection of illegal logging to domestic competition within the US and related effects on competitiveness and US jobs was and is crucial in the US debate on illegal logging.

\section{European Union}

In the EU, the prominence of illegal logging and related trade as a topic culminated in the policy making process that resulted in the adoption of EU Timber Regulation (EUTR, adopted in 2010) (Sotirov 2014, Sotirov et al. 2017), and the debate continued throughout the implementation stage (Schwer and Sotirov 2014; Sotirov et al. 2015, Leipold 2017). The EUTR contains a formal prohibition on placing illegal timber on the EU market and obliges every economic operator who place timber products on the EU market for the first time to exercise due diligence.

The policy discourses surrounding the formulation of the EUTR were marked by heated debates, in particular focussing on a clause prohibiting the placing of illegal timber on the EU market, the relation between legality and sustainability (Sotirov et al. 2017), and the allocation of responsibilities (between 'producer' and 'consumer' countries) concerning illegal logging (Leipold et al. 2016). The topic of illegal logging rose on the European policy agenda in 2002 when the UK Government and British forest administrations, forest industry and ENGOs jointly defined it as a priority issue and set the objective to prepare EU legislation in the matter. The UK became a focal point calling for common European rules for fair competition and sustainable markets (Sotirov 2014). This ultimately led to the adoption of the FLEGT Action Plan in 2003, which applies the logic of 'consumer' countries helping 'producer' countries through voluntary agreements. The European Commission announced later on that further legislative action was needed to complement and strengthen the FLEGT policies (Sotirov et al. 2017).

Following the passage of the US Lacey Act, the idea of closing off EU markets to wood generated from illegal logging increased in salience. Environmental non-governmental organizations (ENGOs) presented European importers as beneficiaries of illegal logging crimes. As a consequence for the European timber importer industry, the protection of their image became a dominant policy priority, and they subsequently called on policy makers to introduce legislation banning illegally logged timber from entering the EU. A coalition pushing for European legislation was formed, made up of these economic groups including associations such as the EU and UK Timber Trade Federations and the Timber Retail Coalition representing leading European retailers, and ENGOs. In terms of the intergovernmental negotiations, the EUTR was supported by member states who significantly depend on timber imports and where the timber import based industry plays an important role (e.g. the UK, the Netherlands and Denmark) as well as by the European Parliament (Sotirov et al. 2017).

At the beginning ENGOs portrayed illegal logging as an issue of sustainability, but once allied with the timber importing industry, sustainability was no longer used and the focus was limited to legality and fair competition. A powerful narrative was developed combining the normative power of environmental moral values with legitimate economic arguments. Key rhetoric figures included presenting the EUTR as a legislation that aimed at prohibiting something illegal (a difficult argument to contradict), and linking illegal logging and deforestation impacts to the high-profile global discussions on climate change. In this way, ENGOs put substantial political pressure on governments and caused opponents to lose credibility when questioning the necessity of demandside actions to curb illegal logging. Once illegal logging started to be debated as a deforestation and climate change issue, there was little legitimate possibility to stop the regulation from being adopted. Next to this environmental morality, industry and business groups further legitimized the discourse as an important trade and industry policy (for eliminating unfair competition on the market) (Sotirov et al. 2017).

In opposition to this narrative, European domestic timber producers (public and private forest owners), (exporting) domestic forest industry, and several forest-rich EU member states (e.g. Austria, Germany, Finland and Sweden) opposed the regulatory changes that were suggested by ENGOs and the European Parliament. The narrative of this coalition emphasized illegal logging as a problem that originated abroad and would be better tackled at its source through policies in the 'producer' countries. Additionally, the regulation was portrayed as unworkable, with major challenges regarding its technical and practical implementation. Their narrative also built on concerns regarding compliance with WTO rules on non-discriminatory trade and proportionate costs and burdens. Since this group of European producers and countries could not be easily portrayed as unscrupulous beneficiaries of crimes in tropical countries (because they were producing in Europe) and were perceived as traditional voices in forestry policy, they were able to maintain considerable influence in the process. Nonetheless, they could not overcome the normative power of the discourse in favour of prohibiting illegal activities (Sotirov et al. 2017).

\section{Australia}

The Australian discourse on illegal logging became particularly prominent in the mid-2000s. The discourse accelerated when domestic industry groups like the softwood and hardwood producers (Australian Forest Products Association, AFPA) and the domestic furniture producing industry (Furnishing Industry of Australia Ltd (FIAA)) called for a measure to close off the Australian market to imports of illegal timber. These debates later resulted in the passage of the Illegal Logging Prohibition Act (ILPA 2012). The dominant narrative in this policy discourse framed illegal logging as a crucial cause of large-scale environmental and social 
degradation, particularly in the Global South. It was not seen as solely caused by weak law enforcement and corruption in countries significantly affected by illegal logging, like Indonesia or Malaysia, two of Australia's major timber trading partners; it was also framed as being caused by Australian firms importing morally questionable goods. According to this framing - which stresses the responsibility of Australian importers and the Australian government - the most suitable solution was to close off the Australian market to illegally harvested or traded timber. This solution was presented as enabling Australia to meet its collective responsibility for the global environment (and particularly forests in the Global South) through the support of legal producers in countries struggling with high rates of illegal logging by granting them preferential market access while forcing out irresponsible or less accountable producers.

The two major groups supporting this narrative, the softwood and hardwood producers (the AFPA) and the domestic furniture producing industry (the FIAA), characterized themselves as honest and caring producers who were disadvantaged by foreign competitors selling assumedly illegal timber for unfairly low prices. This narrative was also supported from an early stage by the Australian Department of Agriculture. Some interviewees even characterized the department as the initiator of the legislative process towards the ILPA, because they commissioned a Jakko Pöyry Management Consulting Report in 2005, which assessed the impact of illegal forest products on the Australian market and predicted market gains for Australian producers if such a law was introduced.

Subsequently, ENGOs like Greenpeace engaged in the ILPA policy-making process. Initially they campaigned against timber importing companies in Australia to move them to support the law. Later, they joined the domestic timber producing industry's story line and built a strategic alliance with them. The Australian ENGOs' story line continued to portray illegal logging as an issue of sustainability even though they allied with the softwood and hardwood producers and the domestic furniture producing industry (cf. Greenpeace Australia Pacific 2011), which aimed to exclude sustainability from the debate. This can be explained by an extension of the strategic alliance to large retailers (understanding themselves as first movers regarding responsible sourcing) and Church groups (stressing wider moral questions like sustainability and proceeds of crime) in Australia (cf. Greenpeace et al. 2013). Australian ENGOs and Church groups particularly promoted a solution strategy to tackle illegal logging by introducing legislation against money laundering; nevertheless, this solution strategy was excluded from the final policy solution, the ILPA (Leipold et al. 2016).

An essentially distinct narrative on illegal logging was promoted by the Australian Timber Importers Federation (ATIF). This narrative portrayed illegal logging as a problem of large exporters of tropical hardwood like Indonesia. As such, it was not seen as Australia's responsibility to develop a solution strategy but rather an issue of the international community, which was already supporting countries seen as predominantly affected by illegal logging with voluntary measures like the Forest Law Enforcement and Governance Initiative. This narrative argued for the logic of assisting 'producer' countries in their domestic efforts to "stop illegal logging where it's happening" (Australian industry representative) instead of tackling the international trade of illegal logs by closing off 'consumer' countries' markets. It portrayed the ILPA as government overreach, potentially impacting importers' competitiveness and thereby threatening Australia's position as an international market place for timber. Notably, this narrative did not succeed in overcoming the normative power of the idea to introduce a law against illegal activities. The domestic wood (products) industry did however actively approach the opposing timber importing industry so as to include the latter's considerations in the design of the ILPA, which was eventually also happening (Leipold et al. 2016).

\section{Narrating illegal logging in 'producer' countries}

\section{China}

In China the discourse over illegal logging has changed substantially in the last 15 years as domestic officials shifted from strongly resisting to accepting legality verification. During this period there were three main narratives that circulated regarding the intentions and potential impacts of legality verification. Initial resistance was based on scepticism that illegal logging was a meaningful concern for Chinese consumers and was instead driven by a Western desire for protectionism. Two other narratives soon appeared, outlining reasons for Chinese support of legality verification. First, a narrative of business pragmatism supported legality verification as being important because international trading partners were demanding it. Second, the forestry management segment of the government determined that support for legality verification fits well into their existing policy initiatives and provides further reason to support their taxation efforts for the granting of timber transportation permits.

The business pragmatism narrative was important for securing the support of internationally oriented timber companies in China. It quickly became clear to the Chinese government that international corporations were committed to following the requirements set by both the EUTR and the US Legal Timber Protection Act. As a country heavily involved in wood processing and production, this meant they would need to follow the demands of these international customers. The Chinese government was reassured to find that the legality verification efforts were not aimed at undermining internal government policy or threatening national sovereignty. While international customers were interested in following rules set by EU and US officials, the main source of revenue for the Chinese wood product industry is the domestic Chinese market. By not destabilizing the domestic market, the illegal logging initiatives were far less concerning to Chinese officials. This ensured that even if most of the industry did not trust Western environmentalist concerns for illegal logging, only those who maintained international customers would be affected. 
Internal bureaucratic power politics within the Chinese government favoured supporting this issue based on a narrative of strengthening state capacity. The Chinese State Forest Administration (SFA) had been granted authority under China's twelfth five-year plan to develop a new national certification scheme. Officials reasoned that they could fold legality verification efforts into this scheme to allow the SFA to have authority to regulate both domestic and international timber within their supply chains. The goal was to protect their existing mechanisms for taxing the transportation of timber. At this time other government departments were seeking to have SFA stripped of that authority in an attempt to lower the tax burden on Chinese businesses. By supporting national forest certification and legality verification, the SFA developed support for their standing taxation efforts.

Central to the Chinese approach to legality verification is a perception that some international environmental programs are designed to undermine the competitiveness of the Chinese wood product industry. This narrative dismissing environmental concerns as a subversive method to reduce developing countries' competitive advantages in timber trade saw legality verification as a program designed to protect faltering Western wood product companies. With time the Chinese government came to recognize that while legality verification has the potential to buttress faltering Western companies, it does not substantially impede the Chinese wood product industry. Rather, complying with legality verification created pressure to streamline existing fragmentation in the wood product supply chains throughout China. While there was some concern that the ultimate burden would fall on small- and mediumsize industry, the industry itself is going through restructuring towards large-scale production due to increasing labour costs and competition from Southeast Asian nations. Furthermore, the limited enforcement of the EUTR and US Lacey Act amendment is seen as not having a significant direct impact on Chinese industry.

\section{Indonesia}

The interest in legality verification within Indonesia has been substantial and this is evident in its progression in the FLEGT programs and negotiations. Indonesia was among the first countries to initiate international negotiations in an effort to halt illegal harvesting within their own borders and presently stands as one of only two to deliver any shipments of legally verified timber. The drivers for these efforts were both environmental and economic concerns. Indonesia faced rapid deforestation following its transition to democracy. While democracy was a welcome end to an oppressive authoritarian regime, the institutional decentralization that followed was associated with a large-scale boom in illegal logging and rapid deforestation as local officials created forest concession permits to enrich themselves (Purwanto 2005). This issue is an essential concern for the Indonesian central government forestry department. Timber concessions were struggling at the same time that large volumes of illegal timber were leaving the country, in part due to weak institutional controls. Accordingly, the Indonesian government saw legality verification efforts as a way to buttress their existing governance efforts and to develop new pathways for enforcement. This effort to return control to the central government became a central narrative for government officials eager to reassert control over local officials. Despite the strong institutional reasons to support legality verification, they remained concerned that if they spent resources to develop certification without any market incentive to support these efforts then they would hurt their competitiveness nationally. For this reason the initial FLEGT negotiations faltered when the EU failed to enact legislation requiring the purchasing of legal timber. It was only after the US Lacey Act Amendment and the passage of the EUTR that the Indonesian government fully committed to developing legality certification nationally.

Indonesia developed a national timber-tracking program, Sistem Verifikasi Legalitas Kayu (SVLK). This was a substantial institutional change made by the government to address illegal logging, but this effort only impacted parts of the issue. Broadly, the industry was worried about low-stocking volume in concessions as well as the expansion of palm oil and mining interests, which were getting priority for land over timber. These pressures formed the basis of the second major supportive narrative, that legality verification would be a way to revitalize the industry and secure preferential trading relationships. Many in the Indonesian timber industry looked to legality verification as a potential form of salvation as they hoped that it would provide secure linkages to trade with the most lucrative markets and provide a price premium based on assurances of legal status. The SVLK sought to help the industry by improving their reputation and pushing the issue of overlapping concession rights to the fore. For instance, if a segment of land has both a mining concession and a timber concession on it, then conflicts over use will arise; the SVLK provides a forum for adjudicating these conflicts.

In this way, much of the policy narrative in Indonesia focuses on the role of streamlining efforts to address institutional confusion, to clarify rights, and to protect the timber industry from falling competitiveness. Indonesia seeks to reduce conflicts in rival industries, to clarify issues in informal ownership rights and to reduce intergovernmental competition. Legality verification provides a market incentive that encourages negotiation relating to these issues. While it has not solved any of these issues, the fact that these efforts have led to dialogue and some legal clarification is already progress. In the long term, the major issue is whether corruption, competition and weak governance will destabilize existing progress or if legality verification will provide sufficient incentives to combat these long standing issues.

\section{Cambodia}

The discourse on illegal logging in Cambodia is highly fragmented. At the time of study, knowledge and awareness about legality verification was practically absent outside the national government agencies and the international community. The narrative of international organizations, donors, and NGOs was, and still is, that illegal logging is one of the main causes of forest loss in Cambodia made possible mainly because high-level government officers are involved and/or benefit (see e.g. Verver and Dahles 2015, Global Witness 
2013). Internationally owned economic land concessions (ELC) and the military are also involved (e.g. Milne and Mahanty 2015, Global Witness 2013, 2009). According to this narrative, illegal logging causes biodiversity loss and has serious implications for rural poor people, a majority of who depends on forestland and forest products (Nathan and Boon 2012). Improved forest governance is a core element of most suggested solutions, ranging from national forest programs to community forestry and large-scale internationally funded programs such as REDD+ and legality verification (Nathan and Pasgaard 2017, RGC 2010, UN-REDD 2011).

The Royal Government of Cambodia has expressed interest in legality verification, but was, at the time of study, not very articulate about illegal logging or its implications, and the topic was sensitive. The Forest Administration (FA) pointed to official statistics showing that Cambodia hardly exported any timber at all. At the time of writing, Cambodia has still not entered actual VPA negotiations with the EU (EFI 2017). Newspapers in English regularly report that government agencies have seized loads of wood from illegal loggers meant for export, imposed fines on the loggers, and/or destroyed it (for instance, Pye and Titthara 2014a). Yet they also report that parts of the seized wood is resold and subsequently exported to China and Vietnam (Pye and Titthara 2014 b). One of the few respondents from the FA that was familiar with legality verification considered these findings "no big issue." Though he appreciated the prospects of EU funding for good governance, he did not expect it would be large enough to make a real difference. Yet he did expect legality verification to become beneficial for Cambodia's planned future export of plantation wood.

The narrative according to local rangers in a national park under the Ministry of Environment was about "influential people" (not necessarily high level government officers) being behind illegal logging, by organizing local people and providing them with chainsaws. The rangers themselves felt they lacked the authority and capacity to deal with the magnitude of the problem. The only thing they could do was to collaborate with local community leaders and try to identify the chainsaw users. In their view, since illegal logs from the national park were sold mainly at local markets, they did not see international legality verification as a solution, at least not the way we presented it to them.

In the 1990s private international forest companies dominated the forest sector in Cambodia (e.g. Billon 2000). In 2002 the government introduced a logging moratorium, and currently very few private timber companies are left in the country. Nevertheless, the Cambodian Timber Industry's Association (CTIA) was still active at the time of research, lobbying for policy change. According to CTIA, illegal logging was not the problem; the problem was that the ELCs were often established in natural forests, but rarely made use of the wood they felled. This was because it was too expensive and difficult for them to get government permission to export, and because they lacked the relevant expertise. Instead, they burned the wood, primarily at night. Cambodia therefore not only loses forest but also huge amounts of revenues. According to CTIA, the government should allow the forest companies back, allow exporting, and recognize legality verification as part of the solution.

At the local level, there is a rapidly growing rural population. There is also an increasing amount of community forest groups, initiated by NGOs and approved by government (e.g. Yeang 2012). When asked about the main causes of deforestation and forest degradation, local people and community forest groups mostly mentioned logging by "high ranking people", the military and other outsiders. They also often mentioned encroachment by local people, including domestic immigrants, who need land for cultivation. The implication is that local people lose access to forest land, forest products, and livelihoods (Nathan and Pasgaard 2017). As part of the solution, the local people we interviewed called for increased government support and for more resources and authority for forest patrols.

\section{Peru}

Concern over illegal logging in Peru intensified since about 2000, when the Peruvian forestry administration tried to promote the forest sector, including to international investors (Cornejo-Arana 2007). This concurred with the enactment of Forestry Law 27308 in 2000. This law changed forest exploitation as it abolished the small concessions of 1,000 ha, which had been created by the Forestry Law of 1974 . Under the 1974 law, an informal system of forest exploitation operated parallel to the formally approved extraction and marketing of timber. At that time, all the actors in the forestry sector were aware that close to $100 \%$ of the extracted timber was illegal. It was expected that the reforms proposed under Law 27308 would improve legality compliance within the forest sector. In addition to the law, the state and ENGOs initiated a targeted crusade to eliminate illegal logging, forming the Multisectoral Commission to Combat Illegal Logging. Though this had no real impact, it made the issue newsworthy (Cornejo, personal communication).

The earliest reference to illegal logging in the media that we are aware of is from 2002. It concerns a report on illegal logging of mahogany in the Peru, Brazil and Bolivia border region (Caillaux and Chirinos 2003). Subsequently, an increasing number of reports on illegal logging emerged (e.g. Aidesep 2007, Cornejo 2007, IEA 2012). Previous analyses on Peru's forest sector had pointed out the negative impact of logging on species and forests, the detrimental impact of debt peonage arrangements on forest communities, and the mismatch between areas authorized for logging and areas actually logged (Chirif 1983); but these were not yet characterized as illegal logging. During much of the 1980s and 1990s Peru was occupied with insurgent groups, who operated in the country's forestry centres, like Pucallpa; as such, the forest sector was mostly dormant during those years. The late 1990s saw the beginning of a progressive national government supporting the revival of the industry.

The debate on illegal logging intensified in the mid-2000s. Especially during the early years, short news articles appeared regularly in specialized online periodicals, for instance Sevicio en Comunicacion Intercultural (http://servindi.org/ nosotros), and also in mainstream newspapers, for instance 
El Comercio. A study on illegal logging in Peru (Mejia et al. 2015) tracked media reports related to illegal logging and other irregularities in forestry related articles; the study found 115 articles between 2006 and 2014 in Ahora and 34 in Impetu, two regional newspapers. Illegal logging was also addressed regularly on television.

Based on this latter analysis, a number of illegal logging narratives can be identified. They emerged to some extent sequentially. These narratives are: illegal logging destroys natural populations of valuable timber species like mahogany and tropical cedar; illegal logging has detrimental impacts on indigenous communities; illegal logging persists because it is condoned and supported by a corrupt forestry administration and it is costing the state important amounts of money; illegal logging is a threat for the Trade Promotion Agreement with the US.

The protagonists are slightly different for the distinct narratives. In the case of high-value timber species depletion, the primary protagonists are professional foresters. In the case of negative impacts for indigenous people, the narrative is especially supported by indigenous groups' organizations, which also take up the narrative of species extinction, likely because this also helps further the support for indigenous groups. A wide group of actors take up the narrative of illegal logging in regards to Peru's international relations; the international trade narrative is seen as a new opportunity to voice their disagreement with illegal logging by them. The narrative on illegal logging and corruption of government agencies and officials fits within the wider civil society concerns and opposition against similar practices especially within the realm of regional governments and is hence supported by ENGOs.

The framing of illegal logging as detrimental for indigenous people has evolved into a narrative of violent exchanges between illegal loggers and indigenous people, the latter have meanwhile begun taking active measures to stop illegal logging in their territories. In recent years, more reference is being made to how illegal logging in Peru is framed in the international discourse. This internationalization of Peru's illegal logging is reflected, for instance, by regular stories on Peru's illegal logging in the New York Times. These stories are subsequently reported as news in Peru's public media.

\section{Summary}

Table 2 provides an overview of the narratives we have identified in the seven regions in this paper.

\section{DISCUSSION - COMPARING ILLEGAL LOGGING NARRATIVES ACROSS THE GLOBE}

Our analysis has revealed a diversity of narratives across different regions relating to the issue of illegal logging and the global legality verification regime. Narratives differ greatly in terms of the overall problem perception, responsibilities, policy preferences and solution strategies.
Taking a closer look, however, reveals some similarities amongst regions. To begin, illegal logging policy narratives are similar amongst the three analysed 'consumer' countries/ regions US, EU and Australia. In each region, one pro-legalityverification and one counter-legality-verification policy narrative were identified. While the former emphasizes the international responsibility of 'consumer' countries and supports regulatory policies foreclosing domestic markets for illegal timber (which have meanwhile been adopted in all three regions), the counter-narratives underline the responsibility of 'producer' countries and the importance of soft international governance approaches. Notably, both narratives depict the respective opposition in an unfavourable light with the pro-narratives suspecting opportunistic or even criminal interests being responsible for the opposition against legality oriented legislation, and the counter-narratives surmising green protectionism and unfair competition as essential motivations of the supporting groups. With these main patterns being similar across the three regions, differences exist regarding the argumentative patterns and the strategic alliances and coalitions that share the respective narratives.

As for the 'producer' countries, the picture is more diverse. In China, the powerhouse of the global forest product market, the narrative emphasizing green protectionism as a major motivation behind Western 'consumer' countries' regulatory policy approaches mirrors the narrative of the critics of legality verification within these 'consumer' countries. At the same time, a pragmatist narrative considers legality verification as an opportunity for Chinese exporters. This mirrors the narrative of the export-oriented forest industry in Indonesia and Cambodia. A third narrative in China supports legality verification as a tool to strengthen state government in domestic forest governance, also to combat competition with other policy sectors. A similar narrative is also found in Indonesia, but in regards to (re-)centralizing forest governance.

For the cases of the developing countries of Peru and Cambodia, the debate on illegal logging seems to be less structured and more fragmented. Several narratives related to illegal logging circulate amongst different societal groups, and the governments' position themselves much more cautiously when confronted with accusations of illegal activities in their territories. This guarded positioning goes together with the finding that in these countries, the knowledge related to legality verification is often limited to a narrow circle of internationally oriented NGOs, industry representatives and government officials, while many other forest experts do not consider the issue to be important, or even know about it.

One interesting finding from our review relates to the debatable distinction between 'producer' countries and 'consumer' countries (which, to recall, neglects the major importance of the 'consumer' countries as producers and vice versa): the degree of internationalization in the respective illegal logging debates differs significantly. In 'producer' countries, the debate focuses more on domestic issues (e.g. national competitiveness, sovereignty, indigenous people, conflicts between industries over concessions) than on global dependencies or global governance. This holds particularly 


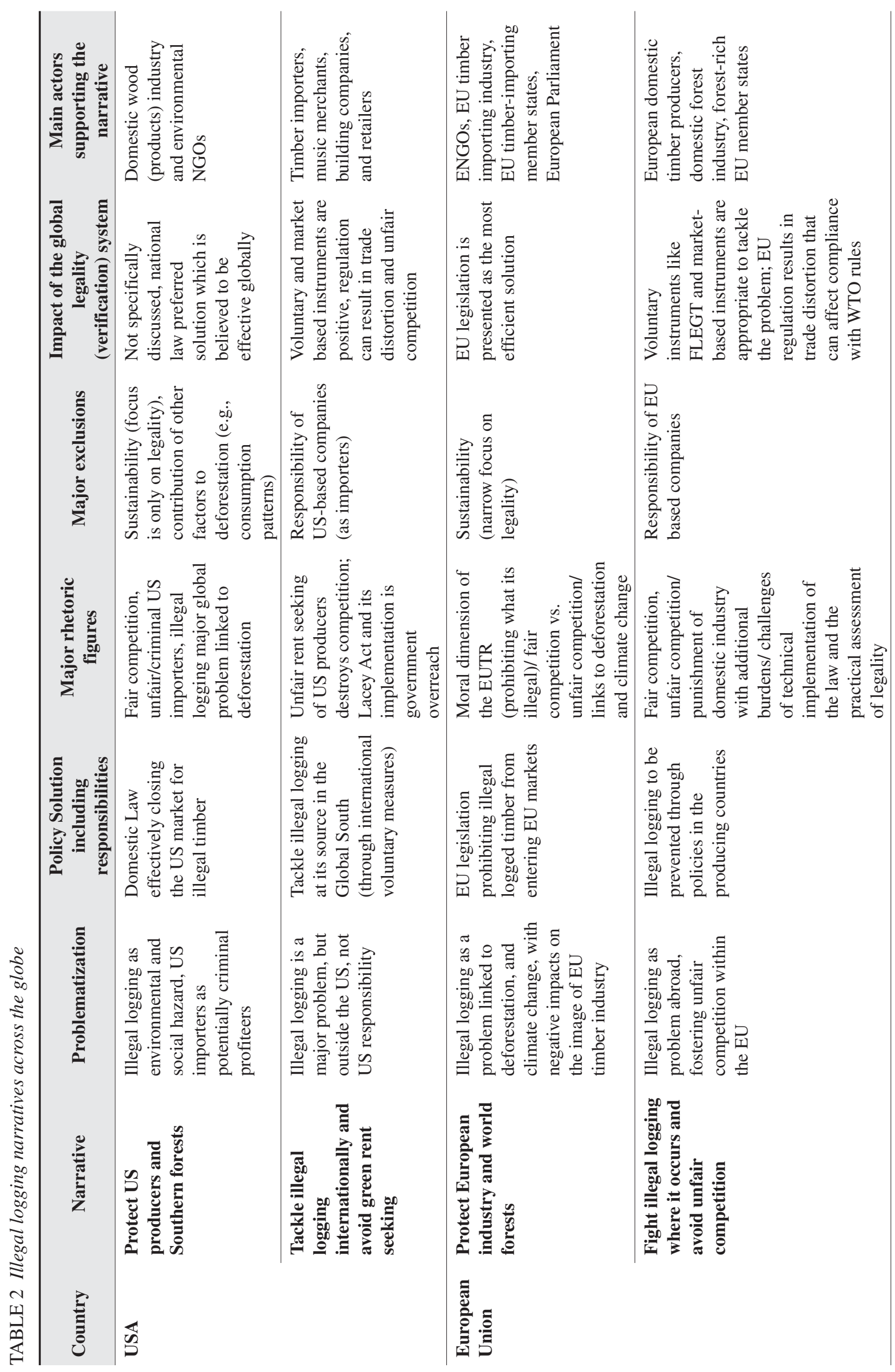




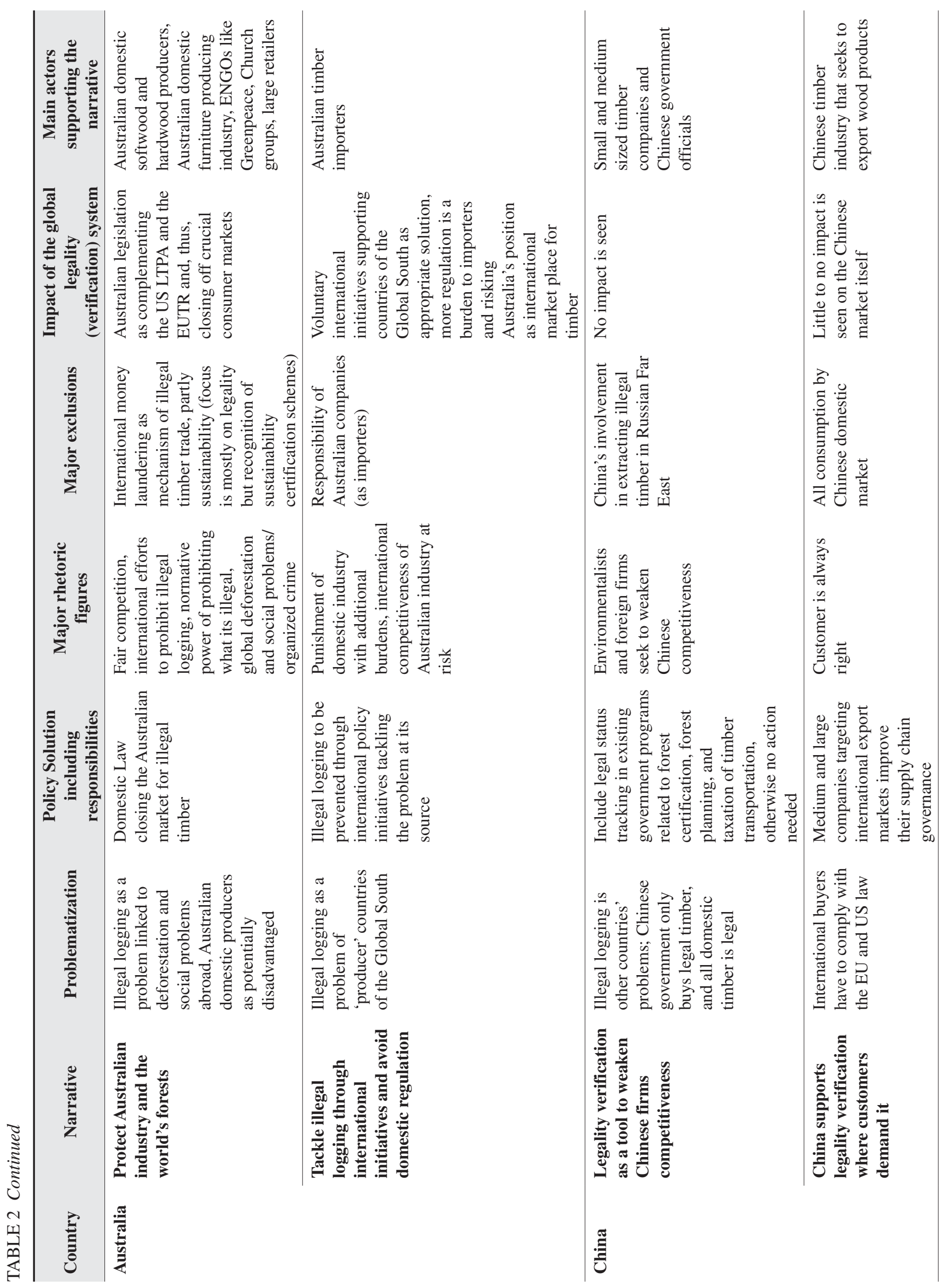




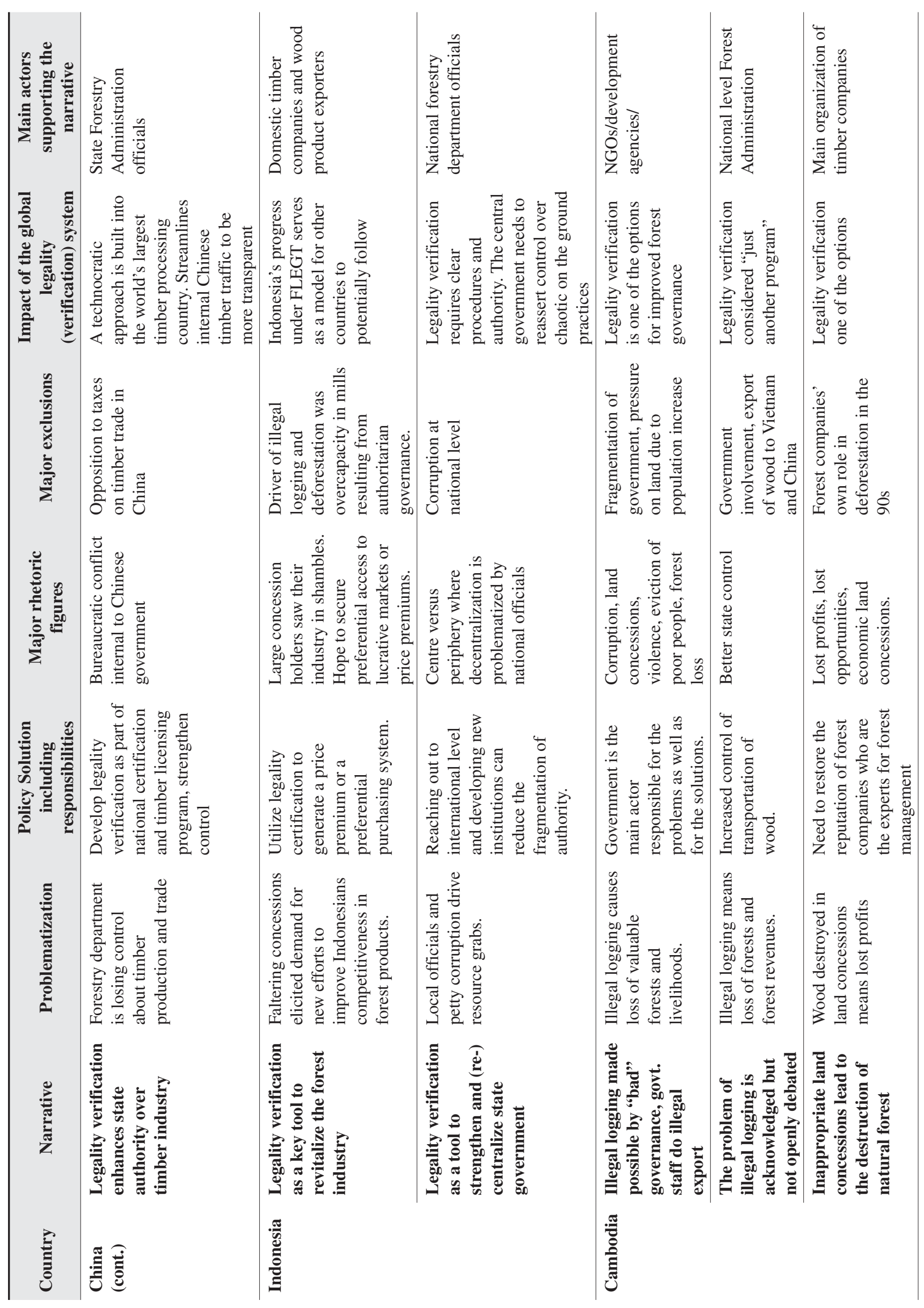




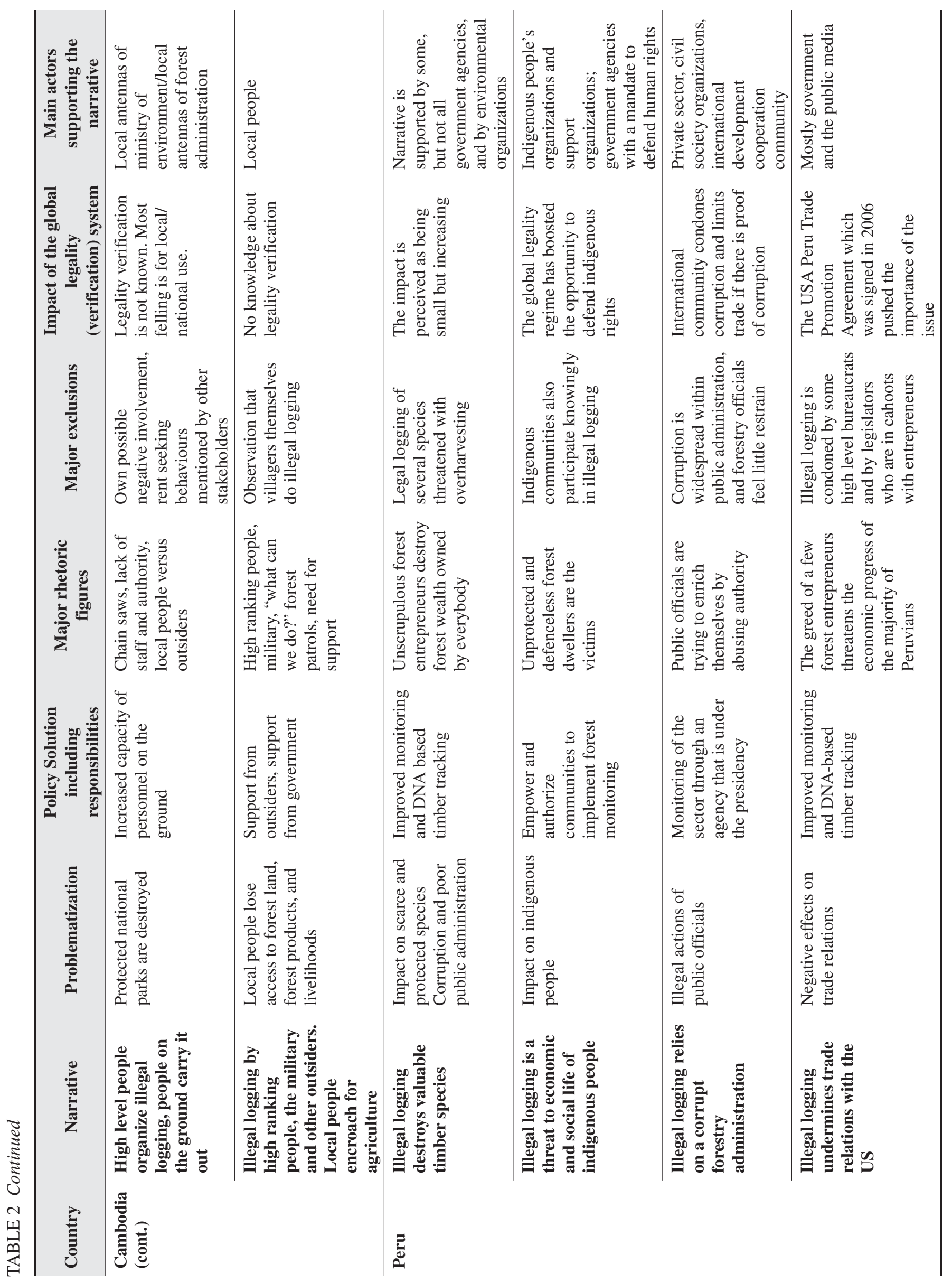


true for the two developing countries we have assessed, Peru and Cambodia. Illegal logging is here connected to a complex array of home-made problems. In line with this finding, these countries rarely discuss forest management practices in other countries, e.g. 'consumer' countries. In contrast, the domestic policy discourses of Australia, the EU and the US focus on forest management practices in the Southern 'producer' countries. While we would like to warn against too far reaching generalizing from these findings, specifically with regard to the diverse set of developing countries, which we have only selectively covered, our findings do indicate an imbalance in the global debate. This imbalance perpetuates the debatable distinction into the 'producing Global South' and the 'consuming Global North' on this issue, which has been established by the latter through the focus on legality instead of sustainability (Leipold and Winkel 2016). And indeed, when it comes to the larger issue of sustainability and how it relates to legality in forest management, the link between both is not strongly expressed in many of the policy narratives we have analysed. In China, Indonesia, Peru and Cambodia it is only partly discussed by NGOs and the social movement; and in Australia, the EU and the US it has been purposefully excluded in the policy discourses as a result of NGOs joining strategic coalitions with industry to enable anti-illegal logging legislation.

Finally, it is interesting to observe different perceptions across the analysed countries when it comes to the evaluation of the effectiveness of an emerging global legality verification regime. Narratives in the 'consumer' countries Australia, the EU and the US seem to largely assume the effectiveness of their domestic policies internationally. In these cases the debates on the positive or negative effects of legality verification is largely connected to the assumption of effective policies that will affect global trade, production and the competitiveness of their domestic industries. On the contrary, in the 'producer' countries China, Indonesia, Cambodia and Peru, the regime's effectiveness is seen as rather limited. These perceptions are also related to the diverging assumptions of the causalities of illegal logging that are narrated in the respective regions, and to the respective exclusions of causalities such as international demand for timber (largely excluded in China, Indonesia, Peru and Cambodia) and complexity of domestic causal factors relating to illegal logging (largely excluded in Australia, the EU and the US).

\section{CONCLUSIONS}

The rise of illegal logging as a top priority issue is connected to a variety of issues and developments in global forest governance, some of which have been discussed for a long time (e.g. concerns about tropical deforestation and debates about decentralization versus central state government), others relating to more recent changes (e.g. the rise of the emerging economies such as Indonesia and China as competitors on the global forest product market). In this paper, we have shown that illegal logging and the global legality verification regime is narrated in very different ways across the globe. This diversity means challenges and, at the same time, opportunities. On one hand, connecting the global regime to distinct domestic narratives - and the related worldviews, perceptions and interests - is probably the only way to make the legality verification regime effective at all. Without creating such connections to domestic policy issues and stakes, the necessary support for the national implementation of policies will likely be missing.

On the other hand, the diversity of narratives across regions does create a major challenge for a global legality verification regime. As this paper shows, support for legality verification comes from very distinct (in some cases hardly complementary) perspectives, against the background of distinct political cultures and related interests. It is an interesting question how far these strikingly different perceptions and related policy strategies can be connected to an overall effective global regime. Moreover, the diversity of interests and motivations linked to legality verification in different regions of the world (ranging from competitiveness, recentralization and re-vitalization of the timber industry to sustainable management and social and ecological issues) raises the question: what objectives can the effectiveness of the regime be measured against and tracked with over time? In our view, the plurality of goals related to legality perception across the globe makes it questionable to assume that the impact and effectiveness of a global legality verification regime can be measured against a priori objectives established by one specific narrative, e.g. the narratives of the supporting ENGOs and industry in Northern 'consumer' countries. Rather, the mosaic of narratives in which the legality verification regime is reproduced across the globe, and which constitutes the regime politically, will translate into a mosaic of perceptions of its impacts and effectiveness. Consequently, further analyses of the legality verification regime need to integrate regionally diverse perceptions (and possibly effects) of the regime.

The strength of the regime may lie precisely in regional support and the ensuing regional effects without a globally shared problem perception, shared policy goals and shared policy solutions. For instance, supporting narratives in China and Indonesia that assume legality verification will foster national competitiveness, law enforcement or trade relations with the global market are likely to promote the implementation of the regime as do ENGOs narratives on legality verification as a basis for the protection of the world's forests. To carefully assess and make use of these distinct perceptions in view of own pursued goals (whether they be related to the competitiveness of the industry, or to environmental sustainability of forestry worldwide) may be the essence of global forest diplomacy in upcoming years, instead of attempting to arrive at a globally shared vision (consensus) on what needs to be done. Skilful policy brokers or mediators, i.e. government officials, international organizations, or even private sector organizations who have credibility and an understanding of the debates on both the international and domestic levels, can play a crucial role to act as discourse agents 
(Leipold and Winkel 2017) and to connecting narratives at different policy levels in order to (incrementally) advance the legality verification regime across the globe.

To assess distinct perceptions of objectives, impacts and effectiveness in different regions of the world remains a major task for future, possibly internationally comparative, research. This research must, on one hand, embrace and analyse the diversity of perceptions of the legality verification regime without implicitly assuming that only one perspective is right. On the other hand, it must also address the crucial question of how the legality verification regime will relate to global forest governance as a whole, i.e. including issues such as sustainability and societal participation. Finally, it would be charming for future work to take up a broader, interdisciplinary perspective and to connect the analysis of policy narratives and perceptions with complimentary analysis of developments relating to global trade or the state of the forests. This paper is meant to pave the ground for such an academic engagement with the legality verification regime as an essential new pillar of global forest governance.

\section{ACKNOWLEDGEMENTS}

We are grateful to our research funders that made the empirical research this paper builds upon possible, namely the German research foundation (DFG) (Australia and US case study; project 'Discursive fragmentation of the international forest regime complex' [PAK 813].), the European Union's Seventh Programme for research, technological development and demonstration (EU case study, INTEGRAL project under grant agreement No 282887), the Eva Mayr-Stihl Stiftung (EU case study), the Danish National Research Council for the Social Sciences (Cambodia case, project 'Ny styrings- og retsformer i multi-level governance' [New Forms of Governance and Law in Multi-Level Governance], project ref. No. 09-065759). The work on Peru was supported by JSPS Grant No 2131015 and Kyoto University Core Stage Backup Fund for 2015 to Wil de Jong. Finally, we are sincerely grateful to our interviewees for the invaluable insights they have provided for our work, and thank Amelia Pope for editing and helpful comments.

\section{REFERENCES}

ASOCIACIÓN INTERÉTNICA DE DESARROLLO DE LA SELVA PERUANA (AIDESEP) 2007. La tala ilegal de caoba (Swietenia macrophylla) en la Amazonía Peruana y su comercialización al mercado exterior. AIDESEP, Lima, Peru.

BARTLEY, T. 2014. Transnational governance and the re-centered state: Sustainability or legality? Regulation \& Governance 8(1): 93-109.

BEVIR, M., and RHODES, R.A.W. 2002. Interpretive theory. In: MARSH, D. (ed.) Theory and Methods in Political Science. Palgrave, Basingstoke et al.
CASHORE, B. and STONE, M.W. 2012. Can legality verification rescue global forest governance? Forest Policy and Economics 18: 13-22.

CASHORE, B. and STONE, M.W. 2014. Does California need Delaware? Explaining Indonesian, Chinese, and United States support for legality compliance of internationally traded products. Regulation \& Governance $8(1)$ : 49-73.

CAILlAUX, J. and CHIRINOS, C. 2003. Tahuamanu, cuando el bosque toca madera. Sociedad Peruana de Derecho Ambiental, Lima, Peru

CHIRIF, A. 1983. El colonialismo interno en un país colonizado: El caso de la Amazonia Peruana. Pp 45-80 in Chirif, Alberto, Saqueo Amazonico. Ediciones CETA, Lima, Peru.

CORNEJO-ARANA, C. 2007. Análisis situacional de concesiones forestales, tala ilegal y titulación de tierras forestales en la Amazonía Peruana. Docuemento de trabajo, IIAP/ Focal Bosque, Iquitos, Peru.

EFI 2017. VPA partner countries http://www.euflegt.efi.int/ vpa (Entered 10/16/2017).

FORESTER, J. 1993. The argumentative turn in policy analysis and planning. Duke University Press.

GAN, J., CERUTTI, P.O., MASIERO, M., PETTENELLA, D., ANDRIGHETTO, N., DAWSON, T. 2016: Quantifying Illegal Logging and Related Timber Trade. In: KLEINSCHMIT, D.; MANSOURIAN, S.; WILDBURGER, C.; PURRET, A. (2016): Illegal logging and related timber trade - dimensions, drivers, impacts and responses. A global scientific rapid re-sponse assessment report. IUFRO World Series 35, Vienna, 119-131.

GLOBAL FORESTRY SERVICES et al. 2014. Understanding timber flows and control in Cambodia in the context of FLEGT. Report prepared by Global Forestry Services, the Forestry Administration of Cambodia and the EU FLEGT Facility, 2014 https://data.opendevelopmentme kong.net/dataset/382db3a6-ee8e-4ee0-8615-0a5830cf3df0/ resource/b202b78e-30ef-4a55-87d2-ad154c4ab9b7/ download/Understanding-timber-flows-and-control-inCambodia-in-the-context-of-FLEGTc.pdf.

GLOBAL WITNESS 2013. Rubber Barons, How Vietnamese Companies and International Financiers are Driving a Land Grabbing Crisis in Cambodia and Laos. London.

GLOBAL WITNESS, 2009. Country for sale: how Cambodia's elite has captured the country's extractive industries, Washington DC.

GLOBAL WITNESS, 2007. Cambodia's Family Trees. Illegal logging and the stripping of public assets by Cambodia's elite, Washington DC.

GOTTWEIS, H. 2003. Post-positivistische Zugänge in der Policy-Analyse. In: MAIER, M.L., HURRELMANN, A., NULLMEIER, F., PRITZLAFF, T., and WIESNER, A. (eds.) Politik als Lernprozeß. Leske Budrich, Opladen, pp. 122-138.

GREENPEACE ET AL., 2009. Eliminating Illegal Forest Products in Australia. A joint forest industry, wood product sector and conservation group statement. http:// www.greenpeace.org/australia/PageFiles/293991/joint statement.pdf (accessed 23/06/2015). 
GREENPEACE AUSTRALIA PACIFIC 2011. Submission to the Senate Illegal Logging Inquiry, March 2011. http:// www.greenpeace.org/australia/PageFiles/300347/ Submission\%20Illegal\%20Logging.pdf (accessed 23.06. 2015).

INTERNATIONAL ENVIRONMENTAL AGENCY 2012. La máquina lavadora cómo el fraude y la corrupción en el sistema de concesiones están destruyendo el futuro de los bosques de Perú. International environmental agency, Lima Peru.

LE BILLON, P. 2000. The political ecology of transition in Cambodia 1989-1999: war, peace and forest exploitation". Development and Change 31(4): 785-805.

LEIPOLD, S. 2017. How to move companies to source responsibly? German implementation of the European Timber Regulation between persuasion and coercion. Forest Policy and Economics 82(2017): 41-51.

LEIPOLD, S., FREI, T., SOTIROV, M. and WINKEL, G. 2016. Protecting "First World" Markets and "Third World" Nature: The Politics of Illegal Logging in Australia, the European Union and the United States. Global Environmental Change 39: 294-304.

LEIPOLD, S. and WINKEL, G. 2016. Divide and Conquer: Discursive Agency and the Politics of Illegal Logging in the United States. Global Environmental Change 36: 35-45.

LEIPOLD, S. and WINKEL, G. 2017. Discursive Agency: $(\mathrm{Re}-)$ Conceptualising actors and practices in the analysis of discursive policy making. Policy Studies Journal 45: 510-534.

MCBETH, M.K., SHANAHAN, E.A., ARNELL, R.J. and HATHAWAY, P.L. 2007. The intersection of narrative policy analysis and policy change theory. Policy Stud. J. 35(1): 87-108.

MCBETH, M.K., SHANAHAN, E.A. and JONES, M.D. 2005. The science of storytelling: measuring policy beliefs in greater Yellowstone. Soc. Nat. Resour. 18(5): 413-429.

MCDERMOTT, C.L., IRLAND, L.C., and PACHECO, P. 2014. Forest certification and legality initiatives in the Brazilian Amazon: Lessons for effective and equitable forest governance. Forest Policy and Economics 50: 134142.

MEJIA, E., CANO, W., DE JONG, W., PACHECO, P., TAPIA, S. and MOROCHO, J. 2015. Actores, aprovechamiento de madera y mercados en la Amazonía peruana. CIFOR Occasional Paper no. 145. Center for International Forestry Research (CIFOR), Bogor, Indonesia.

MILNE, S. AND MAHANTY, S. (EDS.), 2015 Conservation and Development in Cambodia: Exploring New Frontiers in Nature, State and Society.Routledge, Oxford.

NATHAN, I. \& BOON, T.E. 2012. Constraints and Options in Local Forest Management in Cambodia: Is Decentralization a Solution? Journal of Sustainable Forestry Journal of Sustainable Forestry 31: 396-420.

NATHAN, I. \& PASGAARD, M. 2017. Is REDD+ effective, efficient, and equitable? Learning from a REDD+ project in Northern Cambodia. Geoforum 83: 26-38.
OVERDEVEST, C., and ZEITLIN, J. 2014. Assembling an experimentalist regime: Transnational governance interactions in the forest sector. Regulation \& Governance 8(1): 22-48.

ROE, E. 1994. Narrative policy analysis: Theory and practice. Duke University Press.

PURWANTO, S.A. 2005. Forest Resource Management and Self-Governance in Regional Autonomy Indonesia. In M. ERB, P. SULISTIYANTO, and C. FAUCHER (eds.), Regionalism in Post-Suharto Indonesia. Routledge, London.

PYE, D. and M. TITTHARA 2014a. Activists stumped by licence. In The Phnom Penh Post Wed, 6 August 2014 http://www.phnompenhpost.com/national/activistsstumped-licence.

PYE, D. and TITTHARA, M. 2014b. The calculus of logging. Fri, 10 October 2014 http://www.phnompenhpost.com/ national/calculus-logging.

RGC (Royal Government of Cambodia) 2010. National Forest Programme 210-2029. In: THE MINISTRY OF AGRICULTURE FORESTRY AND FISHERIES (ed.), Phnom Penh.

SEARS, R and PINEDO, M. 2011. Forest policy reform and the organization of logging in Peruvian Amazonia. Development and Change 42(2): 609-631

SOTIROV, M. 2014. Changes in environmental governance and illegal logging policies: the case of the European Union's timber regulation. International Forestry Review 16(5): A-33.

SCHWER, S. and SOTIROV, M. 2014. Handel sieht Vor- und Nachteile in EUTR. Europäische Holzhandelsverordnung: Segen oder Fluch für die deutsche und europäische Forst- und Holzwirtschaft? Holz-Zentralblatt 11/2014: 247.

SOTIROV, M., MCDERMOTT, C., DIEGUEZ, L., SELTER, A. STORCH, S. 2015. Integrating footprint thinking into EU forest-related policy - Highlights from research on the Forest Law Enforcement, Governance and Trade (FLEGT) Action Plan as a strategy to address the external impacts of EU consumption. INTEGRAL Policy Brief 4. Available online: http://www.integral-project.eu/images/ Documents/Publications/PolicyBriefs/D4.15\%20Policy $\% 20$ briefs\%204.pdf.

SOTIROV, M., WINKEL, G. and STELTER, M. (2017) The Emergence of the European Union Timber Regulation: How Baptists, Bootleggers, Devil Shifting and Moral Legitimacy Drive Change in the Environmental Governance of Global Timber Trade. Forest Policy and Economics 81: 69-81.

STONE, D.A. 2002. Policy Paradox. The Art of Political Decision Making (rev. ed.). Norton, New York.

UN-REDD 2011: Readiness Preparation Proposal for Cambodia. Forest Carbon Partnership Facility (FCPF) and United Nation's REDD programme.

VAN HEESWIJK, L. and TURNHOUT, E., 2013. The discursive structure of FLEGT (Forest Law Enforcement, Governance and Trade): The negotiation and interpretation of legality in the EU and Indonesia. Forest Policy and Economics 32: 6-13. 
VERVER, M. and DAHLES, H. 2015. The Institutionalisation of Oknha: Cambodian Entrepreneurship at the Interface of Business and Politics. Journal of Contemporary Asia 45(1): 48-70.

WIERSUM, K.F. and ELANDS, B.H. 2013. Opinions on legality principles considered in the FLEGT/VPA policy in Ghana and Indonesia. Forest Policy and Economics 32: 14-22.
WINKEL, G. 2014. When the pendulum doesn't find its center: Environmental narratives, strategies, and forest policy change in the US Pacific Northwest. Global Environmental Change 27: 84-95.

YEANG, D. 2012. Community tenure rights and REDD: a review of the Oddar Meanchey community forestry REDD project in Cambodia. Aust. J. South-East Asian Stud. 5(2): 263-274. 